\title{
Seasonal variation in the diet of wild rabbits Oryctolagus cuniculus on a semiarid Atlantic island (Alegranza, Canarian Archipelago)
}

\author{
María C. MARTÍN, Patricia MARRERO and Manuel NOGALES*
}

\begin{abstract}
Martín M. C., Marrero P. and Nogales M. 2003. Seasonal variation in the diet of wild rabbits Oryctolagus cuniculus on a semiarid Atlantic island (Alegranza, Canarian Archipelago). Acta Theriologica 48: 399-410.

The diet of the wild rabbit Oryctolagus cuniculus (Linnaeus, 1758) on Alegranza Island (Canary Islands) was studied by microhistological examination of faecal samples. We compared the presence of each food-plant species in the faeces across a year in comparison with plant availability. Two areas were studied, Llano de la Vega and La Caldera. At the first site, Suaeda vera and Chenoleoides tomentosa were the most common plants, while at the latter it was Euphorbia regis-jubae. In general, species belonging to the Chenopodiaceae were most commonly eaten by rabbits. Plants such as Chenoleoides tomentosa and Salsola vermiculata were most important in the diet in every season. Levin's niche-breadth was broader across the seasons in the study site of La Caldera than at Llano de la Vega. Furthermore, this parameter yielded the highest values (broadest niche) during the spring at both sites. Most important plants eaten by rabbits showed green vegetative parts through all seasons. Rabbits selected some plants independently of their availability, even in this reduced insular environment. The feeding behaviour of rabbits in Alegranza, selecting certain species, must have had important consequences on the composition and distribution of the vegetation over the years. This negative effect on island vegetation has been shown to occur on many oceanic islands of the world where rabbits have been introduced.

Departamento de Biología Animal (Zoología), Universidad de La Laguna, E-38206, Tenerife, Canary Islands, Spain, e-mail: mnogales@ull.es

Key words: Oryctolagus cuniculus, food selection, plant availability, seasonal variation, microhistological analysis, Canary Islands
\end{abstract}

\section{Introduction}

The Canary Islands represent a biogeographical area of world importance in regard to the number of endemic plant species present, the flora including about 500 such species (Izquierdo et al. 2001). Herbivores constitute one of the major factors threatening the conservation of these plant species. Goats Capra hircus and rabbits Oryctolagus cuniculus (Linnaeus, 1758) in particular include a high percentage of the archipelago's threatened plants in their diets (Rodríguez-Piñero and Rodríguez-Luengo 1993).

\footnotetext{
* Corresponding author
} 
The introduction of large herbivores into the Canaries is dated to the arrival of the original inhabitants about $1000-2000 \mathrm{BC}$ who brought with them goats and sheep Ovis aries. After the Spanish conquest (XVth century) other mammals were introduced, including rabbits. Currently, data on the distribution and abundance of rabbits in these islands are limited but it is known that rabbits occur widely from coastal environments to the mountains on the islands and islets.

This lagomorph has been responsible for the extinction of some insular endemic plants (Flux and Fullagar 1992, Chapuis and Barnaud 1995). Furthermore, surprising cases of plant extinction has occurred in some oceanic islands such as Lisianski and Laysan (Hawaii) where rabbits became almost extinct, due to starvation, after consuming practically all the plants present on those islands (Flux and Fullagar 1992).

Despite the wide presence of rabbits in oceanic islands due to introductions, practically no work has examined the diet of rabbits occupying island habitats. The Canary Islands is not an exception to this and the diet has been poorly studied, the only specific contributions being those of Martín and Marrero (1999) and Marrero and Martín (2000). Particular aspects of the consumption of fruits have been mentioned by Nogales et al. (1995). These studies have been carried out mainly during spring and summer, and no contribution has been focused on the seasonal variation of the diet.

Three main aims were pursued in this research: (1) to study the seasonal variation pattern of the rabbit's diet through a year in a particular semiarid island environment, (2) to determine the temporal use of each food resource in relation to the plant availability and phenology, and (3) to confirm whether rabbits show dietary selection in all seasons in absence of competition with other mammals on a small island where plant diversity is low.

\section{Study area and system}

The Canarian archipelago $\left(27^{\circ} 37^{\prime}-29^{\circ} 25^{\prime} \mathrm{N}\right.$ and $\left.13^{\circ} 20^{\prime}-29^{\circ} 25^{\prime} \mathrm{W}\right)$ is of volcanic origin and is located $100 \mathrm{~km}$ off the Atlantic coast of northwest Africa. This work was conducted on the island of Alegranza, at the northernmost tip of the archipelago located about some $17 \mathrm{~km}$ north of Lanzarote, with an area of $10.2 \mathrm{~km}^{2}$ and a maximum altitude of $289 \mathrm{~m}$ a.s.l. (La Caldera). It was included in the Natural Park of Archipiélago Chinijo and it has been declared as a "Special Zone for the Protection of Birds" by the European Union (Martín et al. 1995). The island has been uninhabited since 1968 and its climate is semiarid, being particularly dry in summer. Average annual precipitation is less than $250 \mathrm{~mm}$ and the mean temperature is $21^{\circ} \mathrm{C}$ (Marzol Jaén 1988). The vegetation consists of a sparse xerophytic shrubland, the most common plants being Chenoleoides tomentosa, Salsola vermiculata, S. divaricata, S. tetranda, Suaeda vera, Euphorbia regis-jubae, Lycium intricatum, Launaea arborescens, and Aizoon canariense, among others (for more information on the vegetation see Kunkel 1971, Rodrigo and González 1984, Marrero 1991). The density and composition of the vegetation have been modified by farming and the introduction of foreign plant species, such as Nicotiana glauca, and herbivores including goats, sheep and rabbits. However, at the end of the 1980s, cattle were eliminated by hunting, but rabbits still remain distributed across the whole island. 
The rabbit was present on Alegranza island at least by the end of the XVIth century (Torriani 1978), but its origin is unknown. It could possibly have come from the Iberian Peninsula (M. Hernández, pers. comm.). On Alegranza, rabbits cause serious damage to the vegetation (Martín and Marrero 1999, Marrero and Martín 2000), just as happened on many oceanic islands around the world (Flux and Fullagar 1992).

The study was carried out at two sites that were chosen because they represented two main vegetation types, both in species composition and structure. The first site of 1.67 ha was situated inside La Caldera, a volcanic crater of $1300 \mathrm{~m}$ diameter; here the most common species were Euphorbia regis-jubae, Salsola vermiculata, S. divaricata and Lycium intricatum. The second site of 3.95 ha was located at Llano de la Vega where Chenoleoides tomentosa, Suaeda vera, Lycium intricatum, and Nicotiana glauca characterised the ground vegetation. At each of these sites a representative vegetation plot of 0.41 ha was chosen for study.

Rabbits were widespread throughout the island and density was calculated in both areas, carrying out 4 censuses in each season, two of them half an hour before dusk and the other 2.5 hour after sunrise. These periods coincide with the highest activity of rabbits, at least in Mediterranean ecosystems on the Iberian Peninsula (Villafuerte et al. 1993). In each area, length of time between censuses was four days and they consisted of a line transect in which 3 persons, walking in a line abreast and spaced $50 \mathrm{~m}$ apart, walked through $750 \mathrm{~m}$ of each study site. We counted only rabbits seen within this $750 \mathrm{~m}$ strip and rabbit mean density through the year was higher in La Caldera (0.87/ha) than at Llano de la Vega $(0.65 /$ ha $)$.

\section{Material and methods}

\section{Faeces collection and analysis}

Field work was conducted for a week of every season (winter: December, January and February; spring: March, April and May; summer: June, July and August; and autumn: September, October and November), between August 1997 and May 1998. About 400 fresh faeces were collected at random in each study site (100 per season and not more than 10 per latrine; $n=10-15$ latrines, approximately), to make sure that they belonged to different individuals. Droppings were located around centres of rabbit activity warrens and we can suppose that most of the collected faeces belonged to individuals that had eaten in the respective plots. All droppings were frozen until analysed using microhistological techniques.

Although the methods used in the microhistological analyses are quite generally employed (Chapuis 1979, Wallage-Drees et al. 1986, Martínez 1988, Duffy et al. 1996, Chapuis et al. 2001), Martín and Marrero (1999) and Marrero and Martín (2000) had previously described in detail the precise methodology performed in the present paper. Some plant fragments could not be identified to species level, but they were classified to family level when possible.

\section{Plant availability}

A vegetation study was carried out to estimate both plant cover (\% cover) and plant biovolume, enabling plant availability to be calculated. Plant cover in each area was obtained by the linear interception method (Kent and Coker 1992), based on arranging linear parallel transects of $25 \mathrm{~m}$, each one separated by $12.5 \mathrm{~m}$. A total of 14 permanent transects were marked out in each site and assessed seasonally. Typically in semiarid environments, plant species grow to form small nuclei (Lacoste and Salanon 1973) and slight variations of the linear transects can produce some bias in the estimation of plant availability. Therefore, it is necessary to make a precise fit of the lines as accurately as possible.

Plant volume was calculated by means of the paraboloide equation $\left(B=1 / 2 \pi r^{2} h\right.$ ), where $B$ is plant volume $\left(\mathrm{dm}^{3}\right), \mathrm{r}$ is radius of the plant $(\mathrm{cm})$ and $\mathrm{h}$ is height of the plant $(\mathrm{cm})$. The results obtained for each species were multiplied by the number of plants recorded in each transect. Data expressed as 
cubic decimetres were transformed to the same units as optic fields with the aim of relating them to the diet (see Marrero and Martín 2000). We also followed the seasonal phenology of the plant species present in the 2 study sites, distinguishing between 2 different stages in the foliage (dry and green).

\section{Statistical and index analysis}

Categorical data analysis (Chi-square tests) were used to study seasonal variations in diet and to compare the rabbit's diet to plant availability. Furthermore, niche-breadth (using \% of frequencies of occurrences of each food item in optic fields) was evaluated using the standardized Levins' niche-breadth index $(B)$, where a value close to " 0 " indicates dietary specialization, and a value close to " 1 " shows a broad diet (Krebs 1989).

\section{Results}

\section{Diet}

Rabbit diet on Alegranza Island was made up of 12 identified plant species and at least three unidentified in the two study sites (Table 1). Ten different species were identified in the diet of the rabbit in Llano de la Vega and 12 in La Caldera. Chenoleoides tomentosa in Llano de la Vega and Salsola vermiculata in La Caldera, 2 perennial shrubs respectively, represented more than $93 \%$ and $73 \%$ of frequency of occurrences, throughout the seasons. Contributions of monocotyledons (mainly grasses) were very low during all seasons $(<1 \%)$ except in spring in La Caldera, when they reached $11.4 \%$.

Levin's niche-breadth $B$ was generally broader in the different seasons in the study site of La Caldera than in Llano de la Vega (Table 2). Furthermore, this parameter yielded the highest values (broadest niche) in the period of spring in the 2 sites. With regards to the plant phenology (Table 3), the most important plants in the diet (Chenoleoides tomentosa, Salsola vermiculata, and S. divaricata) were green throughout the year. Furthermore, of the 8 plant species eaten by rabbits during just one season, 6 were eaten when they were green.

\section{Seasonal variation diet in relation to plant availability}

The seasonal percentage of occurrence of each plant species present in the diet of the rabbit and plant availability in both areas are shown in Fig. 1. Chenoleoides tomentosa was the species mainly consumed in Llano de la Vega (>93\% of optic fields) although there was no significant seasonal variation in the dietary occurrence $\left(\chi^{2}=6.28, \mathrm{df}=3, p=0.09\right)$. However, at La Caldera, where Salsola vermiculata was the plant most commonly eaten by rabbits $(>73 \%)$, there was significant seasonal variation $\left(\chi^{2}=77.40, \mathrm{df}=3, p<0.001\right)$ and this plant was more consumed in summer than in spring (Table 1). The second most commonly eaten plant was Salsola divaricata with percentages between 6.2 and 8.0 except in spring $(1.4 \%)$, with significant seasonal differences $\left(\chi^{2}=25.30, \mathrm{df}=3, p<0.001\right)$. The rest of plants were scarcely eaten, generally with a value less than $10 \%$, except 
Table 1. Seasonal changes in composition of rabbit diets according plant species identified in rabbit faecal pellets from two sites of Alegranza Island (Canaries). Values are expressed in $\%$ of frequency of occurrence in optic fields. Nomenclature of plant species follows Izquierdo et al. (2001).

\begin{tabular}{|c|c|c|c|c|}
\hline \multirow{2}{*}{ Species (Family) } & \multicolumn{4}{|c|}{ Season } \\
\hline & Summer & Autumn & Winter & Spring \\
\hline \multicolumn{5}{|l|}{ Llano de la Vega } \\
\hline Chenoleoides tomentosa (Chenopodiaceae) & 94.0 & 97.0 & 96.2 & 94.6 \\
\hline Patellifolia patellaris (Chenopodiaceae) & 0.2 & 0 & 0 & 0 \\
\hline Suaeda vera (Chenopodiaceae) & 0.8 & 0.6 & 0.4 & 0.8 \\
\hline Aizoon canariense (Aizoaceae) & 1.2 & 0 & 0.6 & 0 \\
\hline Mesembryanthemum sp. (Aizoaceae) & 0 & 0 & 2.0 & 0 \\
\hline Spergularia fallax (Caryophyllaceae) & 0 & 0 & 0 & 0.2 \\
\hline (Poaceae) & 0.4 & 0 & 0.4 & 0.8 \\
\hline Heliotropium ramosissimum (Boraginaceae) & 0 & 0.2 & 0 & 0 \\
\hline Mercurialis annua (Euphorbiaceae) & 0 & 0 & 0.2 & 0 \\
\hline Seeds of Mesembryanthemum sp. & 0.6 & 0 & 29.0 & 3.8 \\
\hline Indetermined & 4.6 & 3.0 & 1.4 & 2.2 \\
\hline \multicolumn{5}{|l|}{ La Caldera } \\
\hline Salsola vermiculata (Chenopodiaceae) & 93.2 & 82.8 & 87.4 & 73.6 \\
\hline Salsola divaricata (Chenopodiaceae) & 6.2 & 8.0 & 7.4 & 1.4 \\
\hline Salsola tetranda (Chenopodiaceae) & 0.2 & 0 & 0 & 0 \\
\hline Suaeda vera (Chenopodiaceae) & 0.2 & 0 & 0 & 0 \\
\hline Patellifolia patellaris (Chenopodiaceae) & 1.4 & 0 & 0 & 0 \\
\hline Aizoon canariense (Aizoaceae) & 1.6 & 0 & 0 & 0.4 \\
\hline Mesembryanthemum sp. (Aizoaceae) & 0 & 0 & 0.2 & 0 \\
\hline Spergularia fallax (Caryophyllaceae) & 0 & 0 & 0 & 0.6 \\
\hline (Poaceae) & 0 & 0.2 & 0.8 & 11.4 \\
\hline Lycium intricatum (Solanaceae) & 0 & 0 & 0 & 0.2 \\
\hline Launaea arborescens (Asteraceae) & 0.4 & 0 & 0 & 0 \\
\hline Seeds of Mesembryanthemum sp. & 0 & 0 & 2.4 & 2.0 \\
\hline Seeds of Aizoon canariense & 1.8 & 0 & 0 & 0 \\
\hline Indetermined & 7.6 & 8.0 & 5.8 & 13.6 \\
\hline
\end{tabular}

Table 2. Standardized Levins' niche-breadth index $B$ of the rabbit diet in Alegranza, based on \% of frequencies of occurrences of each food item in optic fields, in the different seasons and study sites.

\begin{tabular}{lcccc}
\hline \multirow{2}{*}{ Study site } & \multicolumn{4}{c}{ Seasons } \\
\cline { 2 - 5 } & Summer & Autumn & Winter & Spring \\
\hline Llano de la Vega & 0.024 & 0.020 & 0.013 & 0.035 \\
La Caldera & 0.020 & 0.140 & 0.075 & 0.150 \\
\hline
\end{tabular}


Table 3. Seasonal variation of plant phenology of the species eaten by the rabbits in Alegranza. G green plant, D - dry plant. Symbol ( $>$ ) indicates greater abundance of plants in that condition, and symbol (/) represents a similar number of plants in each state.

\begin{tabular}{|c|c|c|c|c|}
\hline \multirow{2}{*}{ Species } & \multicolumn{4}{|c|}{ Season } \\
\hline & Summer & Autumn & Winter & Spring \\
\hline Chenoleoides tomentosa & $\mathrm{G}$ & $\mathrm{D}>\mathrm{G}$ & $\mathrm{D} / \mathrm{G}$ & $\mathrm{G}>\mathrm{D}$ \\
\hline Salsola vermiculata & $\mathrm{G}$ & $\mathrm{G}$ & $\mathrm{D}>\mathrm{G}$ & G \\
\hline Salsola divaricata & $\mathrm{G}$ & $\mathrm{G}$ & G & $\mathrm{G}$ \\
\hline Salsola tetranda & $\mathrm{G}$ & $\mathrm{D}$ & $\mathrm{D}$ & $\mathrm{D}$ \\
\hline Suaeda vera & $\mathrm{G}$ & $\mathrm{G}>\mathrm{D}$ & $\mathrm{D}$ & $\mathrm{D}>\mathrm{G}$ \\
\hline Patellifolia patellaris & $\mathrm{D}$ & $\mathrm{D}$ & $\mathrm{G}$ & G \\
\hline Aizoon canariense & $\mathrm{D}>\mathrm{G}$ & $\mathrm{D}$ & $\mathrm{D}>\mathrm{G}$ & $\mathrm{D} / \mathrm{G}$ \\
\hline Mesembryanthemum crystallinum & $\mathrm{D}$ & $\mathrm{D}$ & $\mathrm{D}$ & $\mathrm{G}$ \\
\hline Mesembryanthemum nodiflorum & $\mathrm{D}$ & $\mathrm{D}$ & $\mathrm{D}>\mathrm{G}$ & $\mathrm{D}>\mathrm{G}$ \\
\hline Spergularia fallax & $\mathrm{D}$ & $\mathrm{D}$ & $\mathrm{D}$ & $\mathrm{D}>\mathrm{G}$ \\
\hline Family Poaceae & $\mathrm{D}$ & $\mathrm{D}$ & $\mathrm{G}$ & G \\
\hline Heliotropium ramosissimum & $\mathrm{G}$ & $\mathrm{G}$ & G & $\mathrm{G}$ \\
\hline Mercurialis annua & $\mathrm{D}$ & $\mathrm{G}$ & G & $\mathrm{G}$ \\
\hline Lycium intricatum & $\mathrm{D}$ & $\mathrm{D}>\mathrm{G}$ & $\mathrm{G}>\mathrm{D}$ & $\mathrm{G}$ \\
\hline Launaea arborescens & $\mathrm{D}$ & $\mathrm{D} / \mathrm{G}$ & $\mathrm{D} / \mathrm{G}$ & $\mathrm{G}$ \\
\hline
\end{tabular}

in particular cases as Mesembryanthemum seeds in Llano de la Vega in winter (29.0\%), an unidentified taxon in La Caldera in spring (13.6\%), and Poaceae in La Caldera also in spring (11.4\%).

With regard to plant availability, in Llano de la Vega, Suaeda vera was common in autumn $(73.3 \%)$ and summer $(57.1 \%)$, whereas Chenoleoides tomentosa was important mainly in spring (58.1\%) and winter (50.6\%). In La Caldera, Euphorbia regis-jubae was the most common species throughout the year (>38\%), the next being Salsola vermiculata, Lycium intricatum, and Salsola divaricata. Comparing annual values of diet versus availability for the most commonly eaten plants (Fig. 1), significant differences were detected for Chenoleoides tomentosa $\left(\chi^{2}=54.40\right.$, $\mathrm{df}=1, p<0.001)$, Salsola divaricata $\left(\chi^{2}=24.21, \mathrm{df}=1, p<0.001\right)$ and $S$. vermiculata $\left(\chi^{2}=94.82, \mathrm{df}=1, p<0.001\right)$, but not for Suaeda vera $\left(\chi^{2}=1.90\right.$, $\mathrm{df}=1, p=0.59$ ).

For some plants consumed in both study areas, such as Aizoon canariense, Mercurialis annua and Patellifolia patellaris, there were no differences in the proportion eaten from one site to the other $(p>0.05)$, but Mesembryanthemum $\mathrm{sp}$. was more commonly eaten during winter $\left(\chi^{2}=8.63, \mathrm{df}=1, p<0.001\right)$ at Llano de la Vega than at La Caldera. 

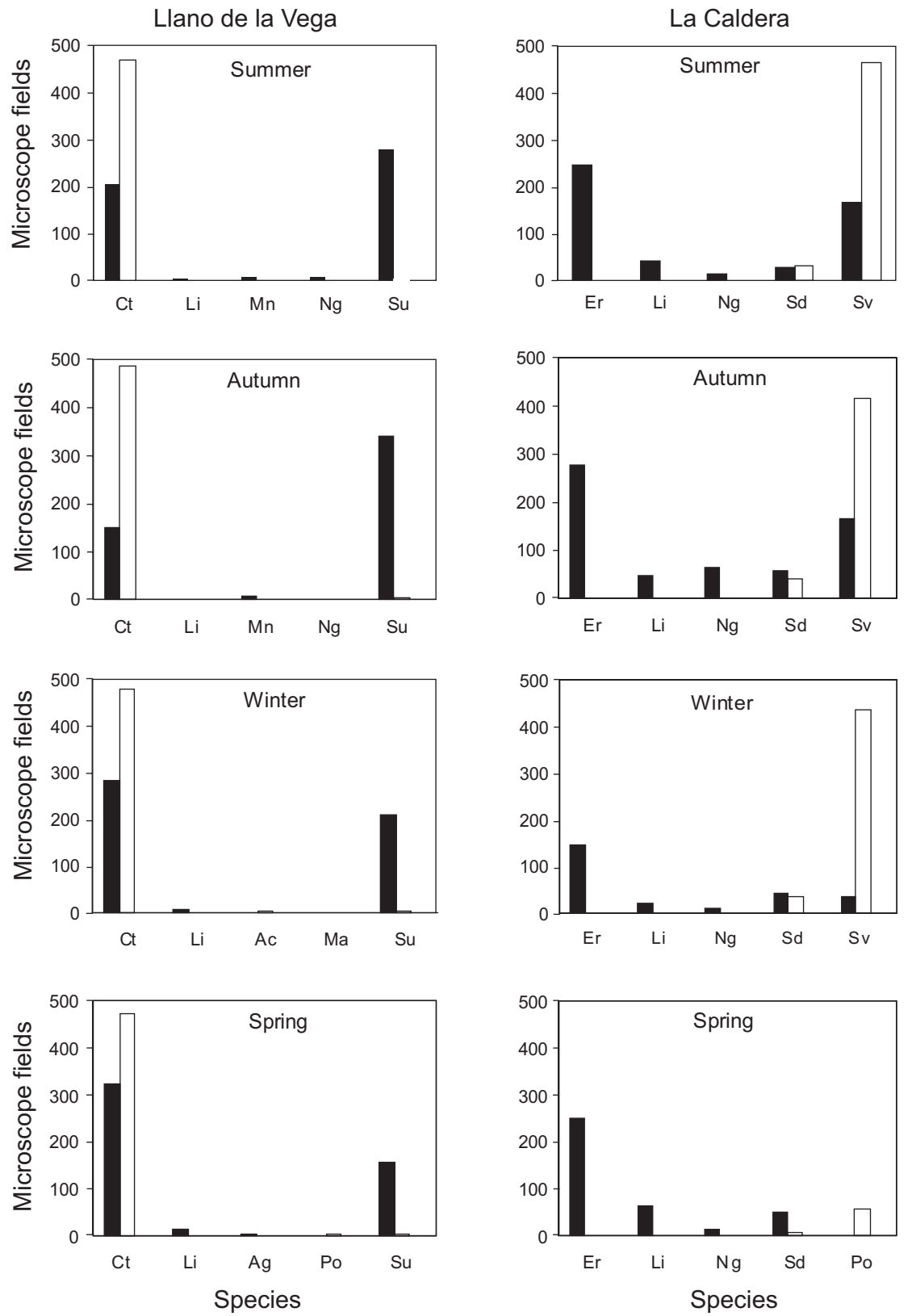

Fig. 1. Comparisons between plant availability (black bars) and rabbit diet (white bars) in Llano de la Vega and La Caldera in the different seasons on Alegranza Island (Canaries). Data from plant availability were transformed to the same units of optic fields with the aim of relating them to the diet. $\mathrm{Ac}$ - Aizoon canariense, $\mathrm{Ag}$ - Atriplex glauca, $\mathrm{Ct}$ - Chenoleoides tomentosa, Er - Euphorbia regis-jubae, $\mathrm{Li}$ - Lycium intricatum, Ma - Mercurialis annua, $\mathrm{Mn}$ - Mesembryanthemum nodiflorum, $\mathrm{Ng}$ Nicotiana glauca, Po - Poaceae, Sd - Salsola divaricata, Sv - Salsola vermiculata, $\mathrm{Su}$ - Suaeda vera. 


\section{Discussion}

\section{Diet}

The study of the diet was carried out by microhistological analysis which is a method that has been widely and satisfactorily used to determine the herbivore diet (Chapuis 1980, Martínez 1988, Cervantes and Martínez 1992, Rogers et al. 1994, Duffy et al. 1996, Chapuis et al. 2001). Although some authors have discussed variation in the accuracy of this method due to different digestibility of plant species (Wallage-Dress and Deinum 1986), others such as Rosati and Bucher (1992) or Chapuis (1980) have argued that the effect on the estimated botanical composition is rarely significant.

Rabbit diet on Alegranza Island was made up of 12 identified plant species and at least 3 unidentified in the two study sites (see Table 1), representing only $13 \%$ of the total taxa present in the island (see Marrero 1991) but $60 \%$ of the species present in the transects of Llano de la Vega and $71 \%$ in La Caldera. Probably, they include in the diet some other species in other parts of the island, when these plants are more locally distributed. However, this reliance on a few species is in agreement with similar studies elsewhere in the world (Chapuis 1979, Crawley 1983, Wallage-Dress and Deinum 1986, Chapuis and Gaudin 1995, Matrai et al. 1998).

Rabbits on Alegranza commonly ate Salsola vermiculata and Chenoleoides tomentosa, which belong to the Chenopodiaceae and show a high concentration of salts. They are generally rejected by rabbits (Myers et al. 1994), perhaps due to their inability to assimilate more than $5 \%$ of these products when the consumption of water does not reach 50\% (Wood and Lee 1985). However, Dawson and Ellis (1979) found that rabbits ate this sort of plant during periods of water restriction. Catling and Newsome (1992) proved that this lagomorph was capable of detecting and selecting specific parts of plants for maximising the intake of proteins and water and decreasing salts. In the case of Alegranza, these Chenopodiaceae species showed a variable proportion of water (64-77\%; Martín and Marrero 1999), even in the dry season (summer), and some of these species (such as Chenoleoides tomentosa or Suaeda vera) would therefore be an important source of water.

Despite the important contribution of monocotyledons (mainly grasses) in the diet of this mammal elsewhere in the world (Soriguer 1988, Chapuis and Gaudin 1995, Duffy et al. 1996), in the present study, these plants were eaten very little during all seasons $(<1 \%)$ except in spring in La Caldera, when they reach $11.4 \%$ of the animal's diet. The low occurrence of monocotyledons in the diet may be due to the usually low rainfall (total annual average around $27.9 \mathrm{~mm}$ ) which inhibited the occurrence of these plants. We also found seeds from Aizoon canariense and Mesembryanthemum sp. in the faeces. The presence of seeds in the diet has been mentioned by other authors (Muñoz 1993, Malo et al. 1995, Nogales et al. 1995, Cerván and Pardo 1997).

Some very common plants were not detected in the rabbit's faeces. This was true of Euphorbia regis-jubae and Nicotiana glauca, which contain several toxic 
products (Pérez and Hernández 1999), which are probably avoided by rabbits, as are other toxic species (Chapuis 1979). However, in Alegranza, some plants of these species showed signs of having been consumed.

The fact that we generally obtained broader Levin's niche-breadth values in the different seasons in the study site of La Caldera than in Llano de la Vega was probably related with the presence of higher plant diversity in this site (see Marrero and Martín 2000). Furthermore, the highest values (broader niche) registered in the period of spring in the 2 sites coincide with the highest number of plant species with green vegetative part of plants.

According to the data on phenology obtained in the present study, rabbits tended to consume those species that showed green shoots, probably because of the presence of water, an element of great importance in this type of arid ecosystem. However, some plant species, as Patellifolia patellaris and Launaea arborescens, were consumed when they bore dry foliage. Plant phenology varies during the year and therefore causes a change in the quality of food, which probably could be beneficial for herbivores (Rogers 1979).

\section{Seasonal diet and plant availability}

The high importance of certain plants in the rabbit's diet through the year, such as Chenoleoides tomentosa and Salsola vermiculata confirms previous indications from the springs of 1996 and 1997 (Martín and Marrero 1999, Marrero and Martín 2000). However, some seasonal plants such as Spergularia fallax, were present in the diet during spring, but in lower percentages than seen in earlier studies (1996 and 1997). This fact is probably related to the higher precipitation in previous years (Martín and Marrero 1999, Marrero and Martín 2000). This shows the opportunistic character of rabbits, changing their diet according to the temporary resources (Chapuis 1979). Moreover, these plant species, which come up after rain, would provide highly digestible food (Cooke 1979).

Comparisons of the food apparently eaten by rabbits with the vegetation available in the two areas indicated that rabbits selected their diet independently of their availability in the environment, even in a place of reduced plant species availability as this island and an in the different seasons and zones. This tendency was previously observed in Alegranza during the springs of 1996 and 1997 by Marrero and Martín (2000).

\section{General considerations and conservation}

All seems to indicate that the selective feeding behaviour of rabbits in Alegranza would surely have had important consequences on plant biodiversity and distribution through the years. This negative effect on the plants of these island environments has been mentioned on many oceanic islands of the world where rabbits have been introduced (Flux and Fullagar 1992). 
It is surprising that none of the approximately 20 endemic plant taxa (see Kunkel 1982), present on the nearby Riscos de Famara (approximately $17 \mathrm{~km}$ distant from the north of Lanzarote Island), have been recorded in Alegranza. Although there is no historical information with respect to that, it is possible that the grazing by rabbits and other larger mammals (as goats and sheep), through at least 4 centuries, has caused the lose of biodiversity and the disappearance of some of these endemic plant species. This phenomenon has been described for other insular territories deserving mention the case of the endemic "chou de Kerguelen" (Pringlea antiscorbutica) (Chapuis and Barnaud 1995). Plants of this species grew from the seed bank after the eradication of this lagomorph. Finally, the eradication of rabbits in Alegranza is highly recommended for the conservation of this ecosystem, which would permit the growing of some of these endemic and other unrecorded plant species.

Acknowledgements: A. Martín gave us all kinds of useful advice. M. A. Hernández, A. Pallarés, J. L. Rodríguez-Luengo and O. Rodríguez provided us with interesting information. B. Cooke, J. L. Chapuis, D. W. Yalden, A. J. Robley, I. A. R. Hulbert and the associate editor L. Rychlik read and made very useful comments that helped decisively to improve the manuscript. We would also like to thank all the friends who helped us during the fieldwork and specially the cooperation of Cabildo de Lanzarote that financed this study. We also thank the Armada Española (Zona Marítima de Canarias) for transporting the researchers and the equipment to Alegranza during the spring 1998.

\section{References}

Catling P. C. and Newsome A. E. 1992. A new technique to determine the seasonal changes in the quality of food selected by free ranging rabbits. [In: Mediterranean-type ecosystems. C. A. Thanos, ed]. Proceedings of the 6th International Conference on Mediterranean-type ecosystems. Meleme, Crete, University of Athens, Athens: 177-182.

Cerván M. and Pardo F. 1997. Dispersión de semillas de Retama (Retama spaerocarpa L.) por el Conejo (Oryctolagus cuniculus L.) en el centro de España. Doñana, Acta Vertebrata 24: 143-154.

Cervantes F. A. and Martínez J. 1992. Food habits of the rabbit Romerolagus diazi (Leporidae) in central Mexico. Journal of Mammalogy 73: 830-834.

Chapuis J. L. 1979. Evolution saisanniere du regime alimentaire d'Oryctolagus cuniculus (L.) dans differents types d'habitats, en France. [In: World lagomorph. K. Myers and C. D. MacInnes, eds]. Proceeding of the World Lagomorph Conference, University of Guelph, Ontario: 743-761.

Chapuis J. L. 1980. Méthodes d'étude du régime alimentaire du lapin de garenne, Oryctolagus cuniculus (L.) par l'analyse micrographique des feces. Revue d'Écologie Terre et Vie 34: 159-198.

Chapuis J. L. and Barnaud G. 1995. Restauration d'îles de l'archipel de Kerguelen par eradication du lapin (Oryctolagus cuniculus): méthode d'intervention appliquée sur l'île Verte. Revue d'Écologie Terre et Vie 50: 377-390.

Chapuis J. L., Boussés P., Pisanu B. and Réale D. 2001. Comparative rumen and fecal diet microhistological determinations of European mouflon. Journal of Range Management 54: 239-242.

Chapuis J. L. and Gaudin J. C. 1995. Utilisation des resources trophiques par le lapin de garenne (Oryctolagus cuniculus) en garrigue sèche aménagée. Gibier Faune Sauvage 12: 213-230.

Cooke B. D. 1979. Food and dynamics of rabbit populations in inland Australia. [In: World lagomorph. K. Myers and C. D. MacInnes, eds]. Proceeding of the World Lagomorph Conference, University of Guelph, Ontario: 633-647. 
Crawley M. J. 1983. Herbivory. The dynamics of animal-plant interactions. Blackwell Scientific Publications, Oxford: 1-437.

Dawson T. J. and Ellis B. A. 1979. Comparison of the diets of yellow-footed rock-wallabies and sympatric herbivores in western New South Wales. Australian Wildlife Research 6: 245-254.

Duffy S. G., Fairley Mria J. S. and O’Donnell G. 1996. Food of rabbits Oryctolagus cuniculus on upland grasslands in Connemara. Biology and Environment: Proceeding of the Royal Irish Academy 96B: $69-75$.

Flux J. E. C. and Fullagar P. J. 1992. World distribution of the rabbit Oryctolagus cuniculus on islands. Mammal Review 22: 151-205.

Izquierdo I., Martín J. L., Zurita N. and Arechavaleta M. (eds). 2001. Lista de especies silvestres de Canarias (hongos, plantas y animales terrestres). Consejería de Política Territorial y Medio Ambiente, Gobierno de Canarias: 1-437.

Kent M. and Coker P. 1992. Vegetation description and analysis. Belhaven Press, London: 1-363.

Krebs C. J. 1989. Ecological methodology. Harper Collins Publisher, New York: 1-654.

Kunkel G. 1971. La vegetación de La Graciosa y notas sobre Alegranza, Montaña Clara y el Roque del Infierno. Monographiae Biologicae Canariensis 2: 47-63.

Kunkel G. 1982. Los Riscos de Famara (Lanzarote, Islas Canarias), breve descripción y guía florística. Naturalia Hispanica 22: 1-118.

Lacoste A. and Salanon R. 1973. Biogeografía. Oikos-Tau S.A., Barcelona: 1-271.

Malo J. E., Jiménez B. and Suárez F. 1995. Seed bank build-up in small disturbance in a Mediterranean pasture: the contribution of endozoochorous dispersal by rabbit. Ecography 18: 73-82.

Marrero A. 1991. La flora y vegetación del Parque Natural de Los Islotes del Norte de Lanzarote y Riscos de Famara. Su situación actual. Comunicaçoes apresentadas nas primeras Jornadas Atlânticas de Protecçao do Meio Ambiente, Angra do Heroismo, Azores: 195-211.

Marrero P. and Martín C. 2000. Spring food preferences of rabbits (Oryctolagus cuniculus L., 1758) on the Islet of Alegranza (Canarian Archipielago). Zeitschrift für Säugetierkunde 65: 246-250

Martín J. L., García H., Redondo C. E., García I. and Carralero I. 1995. La Red Canaria de Espacios Naturales Protegidos. Viceconsejería de Medio Ambiente del Gobierno de Canarias, Santa Cruz de Tenerife: $1-412$.

Martín M. C. and Marrero P. 1999. Dieta primaveral del conejo (Oryctolagus cuniculus L.) en Alegranza, islas Canarias (Lagomorpha, Leporidae). Vieraea 27: 105-113.

Martínez T. 1988. Utilisation de l'analyse micrographique des fèces pour l'étude du régime alimentaire du bouquetin de la Sierra Nevada (Espagne). Mammalia 52: 465-473.

Marzol Jaén M. V. 1988. La Lluvia: un Recurso Natural para Canarias. Servicio de publicaciones de la Caja General de Ahorros de Canarias, Santa Cruz de Tenerife: 1-228.

Matrai K., Altbacker V. and Hahn I. 1998. Seasonal diet of rabbits and their browsing effect on juniper in Bugac Juniper Forest (Hungary). Acta Theriologica 43: 107-112.

Muñoz J. C. 1993. Consumo de gálbulos de Sabina (Juniperus phoenicea ssp. turbinata Guss, 1981) y dispersión de semillas por el Conejo (Oryctolagus cuniculus L.) en el Parque Nacional de Doñana. Doñana, Acta Vertebrata 20: 49-58.

Myers K., Parer I., Wood D. and Cooke D. 1994. The rabbit in Australia. [In: The European rabbit. The history and biology of a successful coloniser. H. V. Thompson and C. M. King, eds]. Oxford Science Publications, Oxford University, Oxford: 108-157.

Nogales M., Valido A. and Medina F. M. 1995. Frugivory of Plocama pendula (Rubiaceae) by the rabbit (Oryctolagus cuniculus) in xerophytic zones of Tenerife (Canary Islands). Acta Oecologica 16: 585-591.

Pérez P. L. and Hernández C. E. 1999. Plantas medicinales o útiles en la flora canaria. Lemus, La Laguna: 1-386.

Rodrigo J. D. and González M. N. 1984. Los islotes del norte de Lanzarote. Aguayro 151: 13-18. 
Rodríguez-Piñero J. C. and Rodríguez-Luengo J. L. 1993. The effect of herbivores on the endemic Canary flora. Boletim do Museu Municipal do Funchal 2: 265-271.

Rogers P. M. 1979. The wild rabbit in the Camargue, Southern France. [In: World lagomorph. K. Myers and C. D. MacInnes, eds]. Proceeding of the World Lagomorph Conference, University of Guelph, Ontario: 587-599.

Rogers P. M., Arthur C. P. and Soriguer R. C. 1994. The rabbit in continental Europe. [In: The European rabbit. The history and biology of a successful coloniser. H. V. Thompson and C. M. King, eds]. Oxford Science Publications, Oxford University, Oxford: 23-63.

Rosati V. R. and Bucher E. H. 1992. Seasonal diet of the Chacoan cavy (Pediolagus salinicola) in the western Chaco, Argentina. Mammalia 56: 567-574.

Soriguer R. C. 1988. Alimentación del conejo (Oryctolagus cuniculus L., 1758) en Doñana SO, España. Doñana, Acta Vertebrata 15: 141-150.

Torriani L. 1978. Descripción e Historia del Reino de las Islas Canarias Antes Afortunadas, con el Parecer de sus Fortificaciones, 1599. Goya, Santa Cruz de Tenerife: 1-298.

Villafuerte R., Kufner M. B., Delibes M. and Moreno S. 1993. Environmental factors influencing the seasonal daily activity of the European rabbit (Oryctolagus cuniculus) in a Mediterranean area. Mammalia 57: 341-347.

Wallage-Dress J. M. and Deinum B. 1986. Quality of the select diet by wild rabbit (Oryctolagus cuniculus (L.)) in autumn and winter. Netherlands Journal of Zoology 36: 438-448.

Wallage-Dress J. M., Immink H. J., De Bruyn G.-J. and Slim P. A. 1986. The use of fragmentidentification to demonstrate short-term changes in the diet of rabbits. Acta Theriologica 31: 293-301.

Wood D. H. and Lee A. K. 1985. An examination of sodium, potassium and osmotic concetrations in blood and urine of arid-zone rabbits in seasonal field conditions and in the laboratory. Australian Wildlife Research 12: 173-182.

Received 20 February 2002, accepted 6 January 2003.

Associate Editor was Leszek Rychlik. 